\title{
Pelaksanaan Program Pembinaan Kemandirian Melalui Kewirausahaan Bagi Narapidana Di Lembaga Pemasyarakatan Kelas IIA Mataram
}

\author{
Dwi Putra Herliansyah \\ Prodi Manajemen Pemasyarakatan Politeknik Ilmu Pemsyarakatan \\ Email: dwiputraherliansyah@gmail.com
}

Received: 10 Maret, 2020; Accepted: 17 Mei, 2020; Published: 27 Juni, 2020

\begin{abstract}
Abstrak
Pembahasan penelitian ini yaitu dalam ruang lingkup pelaksanaan salah satu pembinaan kemandirian yaitu program pembinaan kewirausahaan. Kewirausahaan merupakan suatu perilaku dan kemampuan yang kreatif dan inovatif sehingga dapat dijadikan dasar untuk memperoleh keuntungan melalui suatu keterampilan dalam bidang usaha, selain itu kegiatan kewirausahaan juga dapat dijadikan sebagai suatu program untuk pembentukan perilaku wirausaha pada narapidana. Narapidana adalah terpidana yang sedang menjalani pidana hilang kemerdekaan di Lembaga Pemasyarakatan, Lembaga Pemasyarakatan wajib memberikan suatu wadah untuk para narapidana agar narapidana tersebut dapat menyalurkan minat bakat serta keahlian dan keterampilan mereka. Tujuan peneliti dalam melakukan penelitian yaitu untuk mengetahui pelaksanaan pembinaan kemandirian dan faktor penghambat atau kendala dalam kelangsungan proses pembinaan kemandirian kewirausahaan, dimana setiap proses kegiatan memiliki kendala dalam proses kegiatan tersebut seperti hasil penelitian pada program pembinaan kemandirian di Lembaga Pemasyarakatan Kelas IIA Mataram masih terdapat kendala seperti minimnya anggaran, kualitas dan kuantitas dari petugas itu sendiri serta sarana dan prasarana yang menunjang keberhasilan program pembinaan kemandirian itu sendiri.
\end{abstract}

Katakunci: Kewirausahaan; Lembaga Pemasyarakatan; Narapidana; Pembinaan;

\begin{abstract}
The discussion of this research is within the scope of the implementation of one of the fostering independence of the entrepreneurship guidance program. Entrepreneurship is a creative and innovative behavior and ability so that it can be used as a basis to gain profits through a skill in the field of business, besides that entrepreneurial activities can also be used as a program for the formation of entrepreneurial behavior in prisoners. Prisoners are convicts who are undergoing the crime of missing independence at the Correctional Institution, Correctional Institutions are required to provide a forum for inmates so that prisoners can channel their talents and expertise and expertise interests. The objective of the researcher in conducting research is to find out the implementation of fostering independence and inhibiting factors or obstacles in the continuity of the process of fostering
\end{abstract}


entrepreneurial independence, where each activity process has obstacles in the process of such activities such as the results of research on the

independence fostering program at the Class IIA Mataram Prison there are still obstacles such as the lack of budget, the quality and quantity of the officers themselves and the facilities and infrastructure that support the success of the selfhelp development program itself.

Keywords: Convict; Correctional Institution; Development; Entrepreneurship

\section{PENDAHULUAN}

Sistem kepenjaraan yang diwariskan oleh kolonial belanda yang bertujuan untuk menjadikan orang yang dipidana menjadi jera dan tidak mengulangi tindak pidana nya lagi,sistem ini memperlakukan terpidana dengan cara dihukum atau diasingkan dari masyarakat sebagai balasan akibat perbuatannya.

Pada pasal 1 butir (3) UU No.12 Tahun 1995 dijelaskan bahwa lembaga pemasyarakatan adalah tempat untuk melakukan suatu kegiatan pembinaan untuk narapidana dan anak didik pemasyarakatan di Indonesia. Pemasyarakatan memiliki fungsi untuk menyiapkan warga binaan pemasyarakatan berintegrasi dengan masyarakat sehingga warga binaan pemasyarakatan ini dapat diterima secara baik oleh masyarakat. Lembaga pemasyarakatan menjadi tempat untuk melakukan pembinaan bagi warga binaan pemasyarakatan untuk memberikan pendidikan dan pelatihan kepada narapidana untuk meningkatkan kualitas narapidana agar menyadari kesalahan yang dilakukannya,memperbaiki diri,dan tidak menggulangi tindak pidana lagi . Pentingnya sebuah peran Lembaga pemasyarakatan sebagai wadah pembinaan untuk narapidana yang mampu memberikan sebuah pendidikan dan pelatihan sehingga program pembinaan berjalan sesuai dengan yang di harapkan.

Pelaksanaan program pembinaan untuk narapidana ini sangatlah penting untuk mengembalikan narapidana kepada masyarakat tidak hanya bersifat material maupun spiritual saja melainkan keduanya harus berjalan seiringan. Pembinaan pada lembaga pemasyarakatan diharapkan mampu menciptakan mental dan kepribadian yang baik untuk narapidana, di dalam pelaksanaan pembinaan diperlukan kerjasama terhadap komponen-komponen yang bersangkutan untuk 
menunjang keberhasilan suatu proses pembinaan narapidana. Pelaksanaan pembinaan narapidana ini dikeluarkan oleh Departemen Kehakiman berdasarkan Keputusan Menteri Kehakiman RI No. M.002-PK.04.10 Tahun 1990. Tentang pola pembinaan narapidana dapat dibagi ke dalam 2 (dua) bidang yakni (Bengkalis, 2018)

a. Pembinaan kepribadiaan yang meliputi diantara lain :

1) Pembinaan kesadaran beragama.

2) Pembinaan kemampuan intelektual (kecerdasan)

3) Pembinaan berbangsa dan bernegara

4) Pembinaan mengintegrasikan diri dengan masyarakat

5) Pembinaan kesadaran hukum

b. Pembinaan kemandirian diantaranya yakni :

1) Keterampilan untuk membantu usaha mandiri,misalnya kerajinan tangan,industri dalam rumah tangga,pelatihan reparasi mesin dan alat alat elektronik dan semancamnya.

2) Keterampilan untuk usaha industri kecil,misalnya pengelolaan bahan mentah dari hasil pertanian dan bahan alam menjadi bahan setengah jadi dan menjadi bahan jadi.

3) Keterampilan yang dikembangkan sesuai dengan minat dan bakat para narapidana masing-masing.

4) Keterampilan untuk mendukung suatu usaha industri maupun kegiatan pertanian (perkebunan) dengan menggunakan teknologi madaya atau teknolgi tinggi misalnya percetakan,industri pangan,dan pabrik kulit,

Di dalam 10 prinsip yang menyangkut perlakuan para narapidana salah satunya pekerjaan yang diberikan kepada narapidana atau anak didik pemasyarakatan tidak boleh bersifat mengisi waktu atau bersifat memenuhi kebutuhan jawaban atau kepentingan negara melainkan harus berkaitan dengan pekerjaan yang terdapat di masyarakat yang dapat menunjang pembangunan sekitar lingkungan masyarakat. Seorang narapidana walaupun ia telah melanggar hukum namun masih tetap memiliki hak yang sama seperti masyarakat lain nya, salah 
satunya ialah hak untuk memperoleh pendidikan dan pengajaran . Hal tersebut sesuai dengan pasal 14 ayat (1) Undang-Undang Pemasyarakatan yang dijelaskan bahwa narapidana mempunyai hak yang sama seperti pada umumnya.

Contoh pekerjaan yang dapat diberikan hendaknya dapat mendukung kewirausahaan narapidana,sehingga dapat membiayai diri sendiri serta keluarganya. Sasaran pembinaan itu akan tercapai pelaksanaannya apabila semua unsur turut membantu kelangsungannya sistem. Walaupun narapidana telah tersesat dari segi hukum tetapi hak-haknya sebagai umat manusia tidak boleh direnggut, karena narapidana hanya boleh direnggut hak kemerdekaannya.

Jiwa kewirausahaan itu adalah suatu sikap yang perlu ditanamkan kepada warga binaan pemasyarakatan jiwa tersebut lah yang dituntut masa sekarang karena orang yang memiliki keterampilan atau keahlian suatu saat akan menjadi modal untuk berwirausaha dengan menciptakan lapangan kerja yang baru atau dapat bergabung dengan pengusaha-pengusaha lain. Pada saat ini bahwa seorang yang melakukan tindak pidana karena faktor ekonomi yang rendah dimana sulitnya mencari pekerjaan dan tidak memiliki keterampilan maupun keahlian kerja sehingga orang tersebut mengambil jalan pintas dan melanggar hukum untuk memenuhi kebutuhan hidupnya, akibat perbuatan melanggar hukum maka bertindak kriminal dan akhirnya mereka dijatuhi pidana.pidana yang diberikan kepada pelanggar hukum pada hakekatnya adalah pidana hilangnya kemerdekaan bergerak selama waktu yang telah ditentukan sesuai dengan putusan hakim di pengadilan yang telah mempunyai hukum tetap.

Lembaga Pemasyarakatan kelas IIA Mataram telah melaksanan program pembinaan kemandirian diantara lain : Pembinaan kemandirian berupa pelatihan kerja mandiri,pelatihan pembuatan ukir kayu (cukli),pelatihan cuci mobil dan motor,dan pelatihan pembuatan mebel. Segala jenis program pembinaan kemandirian bertujuan untuk meningkatkan jiwa kreativitas dan memberikan keterampilan kepada warga binaan pemasyarakatan Lapas Kelas IIA Mataram agar nantinnya bisa menjadi bekal bagi narapidana untuk kembali ke masyarakat. 
Pemasyarakatan Kelas IIA Mataram.

\section{METODE}

Rancangan penelitian ini termasuk tipe Eksplanatory Research. Rancangan penelitian yang digunakan oleh peneliti adalah penelitian kualitatif guna untuk mendapatkan informasi atau data-data mengenai peranan Lembaga Pemasyarakatan kelas IIA Mataram dalam melakukan program pembinaan terhadap narapidana. Dan penelitian ini dilakukan dengan cara meninjau langsung ke lokasi tempat penelitian dan melakukan wawancara dengan para informan secara mendalam. Teknik pengumpulan data yang dilakukan oleh penulis dalam penelitian ini menggunakan Observasi dan Wawancara. Adapaun tehnik analisis yang digunakan yakni menggunakan analisis diskriptif kualitatif. Setelah peneliti mendapatkan data yang diperlukan kemudian dikumpulkan secara lengkap dan menyeluruh, data yang telah diperoleh dari hasil peninjaun lokasi akan diuraikan dalam bentuk kalimat.(Sugiyono, 2008)

\section{HASIL PENELITIAN DAN PEMBAHASAN}

Kewirausahaan merupakan komponen penting untuk kemajuan dan kesejahteraan dunia,bahkan kewirausahaan menjadi pertumbuhan ekonomi suatu negara. Kewirausahaan atau biasa dibilang "Entrepreneurship" ialah suatu proses dalam penciptaan sesuatu yang baru (kreasi baru) dan membuat sesuatu yang berbeda dari sebelumnya sedangkan wirausaha lebih mengacu pada orang yang melaksanakan proses kekayaan dan nilai tambah melalui nilai gagasan,memadukan suatu sumber daya dan merealisasikan suatu gagasan menjadi realita. Dengan kata lain, wirausaha adalah orang yang mampu memperdayakan gagasan menjadi realitas. (Surmayanto, 2019)

Dijelaskan dalam Undang-Undang Nomor 12 tahun 1995 pasal 2 tentang Pemasyarakatan bahwa pemberian keterampilan kerja memiliki nilai yang sangat strategis dan penting dalam pembinaan narapidana,hal ini berarti salah satu wujud pembinaan kemandirian dan juga harus bermanfaat secara baik selama yang bersangkutan menjalani pidana maupun selesai menjalani pidana, sehingga warga 
binaan pemasyarakatan memiliki suatu kesempatan yang sama dengan anggota masyarakat yang aktif dan produktif dalam proses pembangunan.

Seorang narapidana yang sedang menjalani masa pidananya akan mengikuti program pembinaan kemandirian, salah satu programnya ialah kegiatan kewirausahaan. Program ini bertujuan untuk melakukan pengembangan mental berwirausaha dimana didalamnya terdapat nilai-nilai kewirausahaan,yakni kepribadian yang memiliki tindakan kreatif,gemar berusaha,memiliki rasa percaya diri ,menumbuhkan self determination atau locus of control dan berkemampuan mengelola resiko.

Upaya untuk meningkatkan mutu dan kualitas sumber daya manusia menjadi acuan guna memperbaiki kesejahteraan masyarakat dalam suatu negara, termasuk untuk narapidana yang harus diberikan pelatihan yang lebih dalam meningkatkan mutu dan kualitasnya untuk tidak menggulangi tindak pidana dan ikut serta dalam proses pembangunan. Memberikan pendidikan dan pembelajaran kepada narapidana mengenai kewirausahaan yang bertujuan untuk meningkatkan wawasan kewirausahaan melalui sikap,pengetahuan dan keterampilan. Pendidikan meningkatkan keberhasilan kewirausahaan narapidana melalui penyediaan pengalaman ,penguasaan,model peran,persuasi sosial dan dukungan dengan melobatkan narapidana ke dalam kegaiatan belajar,dan menjalankan usaha kecil atau simulasi nyata (Siswadi, 2013).

\section{A. Pelaksanaan Program Pembinaan Kemandirian Melalui Kegiatan} Kewirausahaan Bagi Narapidana Pada Lembaga Pemasyarakatan Kelas

\section{IIA Mataram}

Bekerja menjadi salah satu aktifitas yang dilakukan oleh manusia yang memiliki peran penting bukan hanya sekedar menjadi mata pencaharian namum tetapi makna yang lebih dalam lagi yaitu bahwa bekerja merupakan bagian hidup,kehidupan ,dan penghidupan seperti yang diungkapkan oleh Drs.Bambang Margono bahwa selama hidupnya manusia tidak dapat dipisahkan oleh pekerjaan karena beberapa alasan yaitu :

1) Manusia sebagai mahluk biologis yang memerlukan pekerjaan sebagai sumber mata pencaharian untuk memenuhi kebutuhannya. 
2) Manusia sebagai mahluk sosial yang harus dapat menyesuaikan diri terhadap perkembangan masyarakat sehingga menggagap pekerjaan sebagai yang mulia.

3) Manusia sebagai faktor ekonomi yang berfungsi memproduksi barang atau jasa

4) Manusia sebagai mahluk yang berbudaya, yang memandang pekerjaan sebagai suatu kehidupan yang luhur dan terhormat

5) Manusia sebagai mahluk tuhan atau mahluk yang bertuhan memandang bekerja adalah suatu bentuk pengabdian masyarakat

Adapaun langkah-langkah yang ditempuh bidang kegiatan kerja dalam pelaksanaan program pembinaan kemandirian ialah :

1. Tahap Persiapan

Di dalam tahap ini yang dilakukan adalah penentuan petugas yang melaksanakan kegiatan,penelusuran minat dan bakat narapidana,menentukan peserta kegiatan,penentuan waktu dan tempat kegiatan program pembinaan kemandirian.

2. Tahap Pelaksanaan

Dalam tahap ini petugas atau pembina bagian kegiatan kerja melakukan identifikasi kepada narapidana yang akan mengikuti dalam program pembinaan kemandirian kewirausahaan sesuai dengan minat dan bakat,sebelum mengikuti program petugas melihat data narapidana itu sendiri yang meliputi :

a. Riwayat hidup

b. Riwayat pekerjaan

c. Riwayat kesehatan

d. Riwayat pendidikan

Setelah melihat data para petugas melakukan wawancara kepada narapidana yang bersangkutan untuk mengetahui keahlian dan keterampilan.

3. Tahap penempatan

Pada tahap terakhir ini ditentukan narapidana yang mempunyai keahlian dan kemampuan untuk mendapatkan keterampilan kerja melalui proses 
pendidikan dan pelatihan terlebih dahulu. Kemudian, petugas melakukan pembuatan dan penentuan jaringan kerja yang sesuai dengan kelompok program pembinaan kemandirian kewirausahaan.

\section{Tabel 1}

Data narapidana yang mengikuti program pembinaan kemandirian kewirausahaan di Lembaga Pemasyarakatan kelas IIA Mataram

\begin{tabular}{clc}
\hline NO & \multicolumn{1}{c}{ NAMA } & PROGRAM \\
& & KEWIRAUSAHAAN \\
\hline & & Unit Cukli \\
\hline 1 & Gede Wayan Agus Bin Wayan & Unit Cukli \\
\hline 2 & Rizky Suprianto Bin Kiki & Unit Cukli \\
\hline 3 & Adi Baskoro Bin Koro & Unit Cukli \\
\hline 4 & Abd.Aziz Bin Abdul & Unit Cukli \\
\hline 5 & Muchtar Irawan & Unit Mebel \\
\hline 6 & Dadang Bin Gofur & Unit Mebel \\
\hline 7 & Aslam Nudin Bin Nudin & Unit Mebel \\
\hline 8 & Herdi Abdullah Bin Waang & Unit Mebel \\
\hline 9 & Junaedi Rino Bin Jun & Unit Mebel \\
\hline 10 & Sabar Fitrah Bin Sabar & Unit Cuci Mobil Dan \\
\hline 11 & Karim Lukman Bin Lukman & Motor \\
\hline 12 & Hadi Ahmad Bin Hadi & Motor \\
\hline
\end{tabular}

\section{Jenis Program Pembinaan Kemandirian Kewirausahaan}

Program yang diberikan kepada narapidana sedapat mungkin diarahkan kepada jenis-jenis keterampilan dan keahlian yang bermanfaat di lingkungan masyarakat dan berharap narapidana dapat mengembangkan lebih lanjut sehingga dapat berguna bagi narapidana setelah mereka selesai menjalani masa pidananya. Berikut jenis program pembinaan kemandirian kewirausahaan yang dilakukan Lembaga Pemasyarakatan Kelas IIA Mataram anatara lain :

a. Ukiran kayu (Cukli)

Dalam program kegiatan ini narapidana belajar keterampilan dimana narapidana belajar mengukir kayu dengan motif yang sudah 
ditentukan,dan juga mengukir meja dan barang lainnya menjadi bermotif.

b. Pelatihan cuci mobil dan motor Dalam program kegiatan ini narapidana belajar dan diberi keterampilan teknik cuci mobil dan motor dimana narapidana juga diajarkan mevakum mobil dan diajarkan untuk melakukan waxing dengan kompon.

c. Pembuatan mebel

Dalam program kegiatan ini narapidana diberi keterampilan membuat seperti kursi,meja,dan lemari.

Dalam melaksanakan program kegiatan ini diperlukan pelatih maupun instruktur. Dari pengamatan peneliti setelah melakukan survei lapangan bahwa tenaga pelatih atau instruktur masih sangat minim sehingga pelatih atau instruktur diambil dari kalangan narapidana itu sendiri yang benar benar memiliki keahlian dan kemampuan untuk dapat mengajarkan keahliannya. Hal ini dilakukan karena penghuni di Lembaga Pemasyarakatan ini yang jumlahnya sebanyak 1029 orang terdapat berbagai kalangan mulai dari mereka yang tidak berpendidikan sampai yang bergelar profesor. Seperti, yang dikemukakan oleh informan "GA" kepada peneliti. "kita hanya memanfaatkan penghuni yang mempunyai keahlian dibidangnya untuk dijadika pelatih maupun instruktur karena disini seperti kita ketahui terdapat berbagai sumber daya manusia mulai dari orang yang tidak berpendidikan sampai orang yang memiliki gelar tinggi sampai profesor pun ada disini sehingga kita dapat mempergunakan tenaga tersebut untuk membantu pelatih atau intruktur yang ada"(wawancara terhadap petugas di bidang bimbingan kegiatan kerja tanggal 29 Januari 2020)

\section{B. Faktor-faktor penghambat dan kendala dalam pemberian program kegiatan kerja}

Dalam proses pemberian program kegiatan kewirausahaan merupakan hal yang wajar apabila ditemui adanya berbagai masalah yang menjadi kendala bagi 
keberhasilan pelaksanaan suatu kegiatan. Hal ini terjadi di tempat penulis melakukan penelitian. Adapun permasalahan yang ditemui dalam proses pemberian program kegiatan tersebut diantara lain :

1) Petugas

Petugas memiliki peran penting dalam proses pemasyarakatan,artinya berhasil atau tidaknya proses pembinaan kemandirian ini sangat tergantung kepada petugas yang bersangkutan, sebab untuk meningkatkan mutu dari program pembinaan ini haruslah ditangani oleh seseorang yang mampu menguasai bidang keterampilan,sehingga mampu mencapai tujuan dari program pembinaan kemandirian ini. Selain itu juga masih kurangnya kualitas dan kuantitas petugas dalam pemberian program kegiatan ini karena kurang didukung oleh petugas atau tenaga profesional yang memiliki managerial skill dan technical skill yang memadai,sehingga pelatihan dan pengajaran yang diberikan tidak dapat diterima dengan baik oleh narapidana.

2) Sarana dan Prasarana

Dalam proses pemberian pelatihan dan pengajaran kepada narapidana sangat memerlukan alat-alat yang memadai guna menunjang program kegiatan kewirausahaan ini. Apabila sarana dan prasarana yang ada dapat terpenuhi dan digunakan secara efektif, maka proses pemberian program kegiatan kewirausahaan ini akan berjalan dengan lancar dan mempermudah untuk menentukan keterampilan yang sesuai dengan minat dan bakat narapidana. Sarana dan Prasarana yang berada di Lembaga Pemasyarakatan kelas IIA Mataram saat ini masih sangat terbatas, sebagian besar kurang berfungsi perlu adanya perbaikan dan mesin-mesin alat-alat keterampilan kerja yang keadaannya sudah tidak memadai. Pada kenyataannya,penyedian sarana dan prasarana membutuhkan biaya yang tinggi termasuk perawatan dan penjagaannya. Sementara disatu sisi anggaran program pembinaan kemandirian masih sangat terbatas dan belum sepenuhnya profit oriented.

3) Anggaran 
Anggaran merupakan salah satu faktor penting dalam proses program pembinaan kemandirian ini,keterbatasan anggaran berakibat pada proses kegiatan dan berakibat pada pemeliharaan peralatan terutama mesin-mesin yang ada,sehingga biaya untuk program pembinaan kemandirian kewirausahaan ini relative masih sangat kecil.

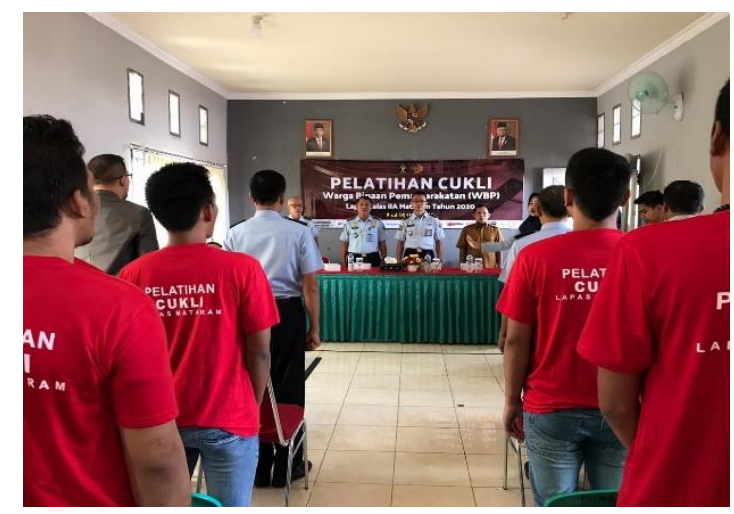

Gambar.1 Pembukaan Program Pelatihan Dan Pengajaran Bagi Narapidana Oleh Kepala Lembaga Pemasyarakatan Kelas IIA Mataram

\section{KESIMPULAN}

Berdasarkan hasil penelitian di Lembaga Pemasyarakatan kelas IIA Mataram peneliti dapat disimpulkan bahwa Pelaksanaan program pembinaan kemandirian melalui kegiatan kewirausahaan bagi narapidana di Lembaga Pemasyarakatan kelas IIA Mataram sejauh ini berjalan dengan baik walaupun terdapat beberapa faktor yang dapat menghambat proses pembinaan tersebut. Yang diharapkan dari program pembinaan kewirausahaan ini narapidana dapat memiliki jiwa kewirausahaan serta memiliki keterampilan dan keahlian suatu saat akan menjadi modal untuk berwirausaha dengan menciptakan lapangan kerja yang baru atau bergabung dengan pengusaha-pengusaha lain, sehingga narapidana dapat diterima kembali oleh masyarakat dan ikut serta dalam proses pembangunan negara.

Didalam pelaksanaan program pembinaan kemandirian kewirausahaan di Lembaga Pemasyarakatan Kelas IIA Mataram terdapat beberapa faktor penghambat dan kendala dalam proses kegiatan tersebut diantara lain: a). 
Kurangnya kualitas dan kuantitas petugas di bidang kegiatan kerja sehingga pelatihan dan pengajaran yang diberikan tidak dapat diterima secara efektif. b). Sarana dan Prasarana yang berada di Lembaga Pemasyarakatan Kelas IIA Mataram masih kurang memadai dan masih sangat terbatas. c). Minimnya anggaran pada proses pembinaan kemandirian kewirausahaan sehingga proses kegiatan tersebut tidak berjalan dengan lancar.

\section{DAFTAR RUJUKAN}

Bengkalis, K. (2018). Pelaksanaan Pembinaan Kemandirian Narapidana Di Lembaga Pemasyarakatan Kelas Ii A Bengkalis Kabupaten Bengkalis Oleh. Jurnal Kewirausahaan, 1, 25-40.

Siswadi, Y. (2013). Analisis Faktor Internal, Faktor Eksternal Dan Pembelajaran Kewirausahaan Yang Mempengaruhi Minat Mahasiswa Dalam Berwirausaha. 13(1), 1-17.

Sugiyono. (2008). Metode Penelitian Pendidikan:(Pendekatan Kuantitatif, Kualitatif Dan $R \& D$ ). Alfabeta.

Surmayanto. (2019). Kewirausahaan (Sulistiono, Ed.). Mutiara Aksara. 